\title{
Molecular evaluation of piroplasms and hematological changes in canine blood stored in a clinical laboratory in Niterói, Rio de Janeiro
}

\author{
Avaliação molecular de piroplasmídeos e alterações hematológicas em \\ amostras de sangue de cães armazenadas em laboratório de análises clínicas \\ de Niterói, Rio de Janeiro
}

Fernanda Barbosa dos Santos; Gilberto Salles Gazeta²; Laís Lisboa Correa; Lucas Fernandes Lobão; João Pedro Palmer ${ }^{1}$; Laís Verdan Dibi,4; José André Lessa Damasceno ${ }^{3}$; Nicole Oliveira Moura-Martiniano²; Otilio Machado Pereira Bastos'; Claudia Maria Antunes Uchôa'; Alynne da Silva Barbosa ${ }^{1,4 \star}$ (1)

${ }^{1}$ Departamento de Microbiologia e Parasitologia, Instituto Biomédico, Universidade Federal Fluminense - UFF, Niterói, RJ, Brasil
${ }^{2}$ Laboratório de Referência Nacional em Vetores das Riquetsioses, Instituto Oswaldo Cruz,
Fundação Oswaldo Cruz - Fiocruz, Rio de Janeiro, RJ, Brasil
${ }^{3}$ Centro de Diagnóstico Veterinário PCA, Niterói, RJ, Brasil
aboratório de Toxoplasmose e outras Protozooses, Instituto Oswaldo Cruz, Fundação Oswaldo Cruz - Fiocruz, Rio de Janeiro, Brasil

How to cite: Santos FB, Gazeta GS, Correa LL, Lobão LF, Palmer JP, Dib LV, et al. Molecular evaluation of piroplasms and hematological changes in canine blood stored in a clinical laboratory in Niterói, Rio de Janeiro. Braz J Vet Parasitol 2020; 29(3): e012420. https://doi.org/10.1590/S1984-29612020057

\begin{abstract}
Piroplasm species were analyzed by molecular tools in total 31 blood samples from positive dogs, previously checked by stained slides, stored until DNA extraction between 2016 to 2018 in the laboratory Clinical Analyzes in Niterói, Rio de Janeiro. The piroplasms were identified by PCR, targeting the $18 \mathrm{~S}$ rRNA gene and sequencing. From the total number of samples only 24 (77.4\%) were positive and show adequate nucleotide sequences for interpretation with identity between 93\%-100\% with Babesia vogeli in compared to the sequences isolated of infected dogs from other states in Brazil deposited on GenBank. Most of dogs infected with B. vogeli had anemia (62.5\%) and thrombocytopenia (95.8\%). The findings of this study are compatible with previous reports in the literature and highlight $B$. vogeli as the most incriminated species in canine piroplasmosis in Brazil, and thrombocytopenia the hematological alteration most frequently identified in this infection. It is important to note that this is the first study involving the molecular characterization of piroplasms in the metropolitan region of Rio de Janeiro, based on PCR followed by sequencing.
\end{abstract}

Keywords: Babesia vogeli, babesiosis, canids.

\begin{abstract}
Resumo
Espécies de piroplasmídeos foram analisadas por meio de métodos moleculares, em 31 amostras de sangue de cães, previamente verificadas em lâminas coradas, estocadas até a extração de DNA entre 2016 a 2018 em laboratório de Análises Clínicas, em Niterói, Rio de Janeiro. Os piroplasmídeos foram identificados pela PCR, utilizando-se como alvo o gene $18 \mathrm{~S}$ RNAr e, posteriormente, o sequenciamento. Do total de amostras analisadas, somente $24(77,4 \%)$ foram positivas e apresentaram sequências nucleotídicas adequadas para interpretação com identidade variando entre $93 \%$ a $100 \%$ com B. vogeli, em comparação com as sequências isoladas de cães infectados de outros estados do Brasil, depositadas no GenBank. A maioria das amostras de sangue dos cães detectados com B. vogeli apresentaram, no hemograma, anemia (62,5\%) e trombocitopenia (95,8\%). Os resultados detectados neste estudo estão compatíveis com o evidenciado na literatura, pois $B$. vogeli tem sido a espécie mais relatada nas infecções caninas no Brasil, sendo a trombocitopenia a alteração hematológica mais evidenciada nas amostras analisadas. É importante ressaltar que este é o primeiro estudo envolvendo análise molecular e caracterização de piroplasmídeos, em amostras de sangue de cães da região metropolitana do Rio de Janeiro, utilizando-se a PCR associada ao sequenciamento.
\end{abstract}

Palavras-chave: Babesia vogeli, babesiose, canídeos.

Received May 23, 2020. Accepted June 10, 2020

*Corresponding author: Alynne da Silva Barbosa. E-mail: alynnedsb@gmail.com

This is an Open Access article distributed under the terms of the Creative Commons Attribution License, which permits unrestricted use distribution, and reproduction in any medium, provided the original work is properly cited. 


\section{Introduction}

The order Piroplasmida includes several genera and species that infect domestic and wild canids (Sousa et al., 2017). These protozoa are transmitted to mammals through the blood meal of infected ticks. In general, the genus Babesia stands out in the group of piroplasms that infect dogs (Bilić et al., 2018). Initially, these species were classified according to its morphology in erythrocytes in "large" (2.5-5.0 $\mu \mathrm{m}$ long) and "small" (1.0-2.5 $\mu \mathrm{m}$ long) forms being recognized as B. canis and B. gibsoni, respectively (Laha et al., 2015). Later, subspecies of B. canis were proposed because, although they were morphologically identical, they had different tick vectors, cross-immunity, and pathogenicity. With the advent of molecular phylogenetic analysis, in particular that of the 18S rRNA gene, it was recognized that the subspecies are in fact distinct species, mainly B. rossi, B. canis, and B. vogeli (Irwin, 2009; Köster et al., 2015; Bilić et al., 2018). Babesia canis is endemic in Europe but has been reported sporadically around the world, $B$. rossi is endemic in South Africa and $B$. vogeli is found worldwide. Already $B$. gibsoni, is the most prevalent of the "small" Babesia, because is endemic in Asia and also occurs sporadically in the rest of the world (Köster et al., 2015). In general, in South American including Brazil, there is a predominance of canine infection by $B$. vogeli and B. gibsoni (Maggi \& Kramer, 2019).

The clinical and pathological changes that occur in infected dogs differ between Babesia species. Once they have been infected, these animals may show signs of anemia and lethargy, and in the most severe cases, multiple organ dysfunction (Bilić et al., 2018). Subclinical infections are common in adult dogs infected with $B$. vogeli, but puppies tend to present with marked anemia (Schoeman, 2009; Bilić et al., 2018). Infection with B. gibsoni, a small Babesia, mostly causes mild signs which are manifested as a subclinical infection or associated with weight loss and weakness. Subclinical infection is common in the USA connected to Pit Bull Terriers (Bilić et al., 2018).

The diagnosis of babesiosis is made by demonstrating the presence of piroplasms within erythrocytes by microscopic techniques. Microscopic diagnostic tests are simple and accessible, requiring a well-prepared and suitably stained blood smear together with a trained observer (Taboada \& Merchant, 1991). Although morphometry is widely used in the diagnosis of babesiosis, its is not possible to differentiate piroplasms species, such as Babesia (Bilić et al., 2018).

Serological tests, as indirect fluorescent antibody test (IFAT) and enzyme-linked immunosorbent assay (ELISA) are employed to diagnose anti - Babesia antibodies in the serum, at the screening level, for both surveillance and research. However, the diagnostic value of serological tests is poor in the absence of clinical signs and patient's data, because the antibodies in dog remain months or years after the infection (Dantas-Torres \& Figueiredo, 2006). The polymerase chain reaction (PCR) associated with the sequencing is a sensitive and specific diagnostic technique which is frequently employed for diagnosis of Babesia in blood samples. It is particularly useful for the detection of the infection in dogs with low parasitemia levels and for differentiation with parasites. Ribossomal genes 18S, 5.8S, 28S and the internal transcribed spacer (ITS) sequences have been the most used for conventional PCR (Irwin, 2009; Bilić et al., 2018).

In Brazil, few studies have been recovered from the literature that used the polymerase chain reaction followed by sequencing to accurately identify the species of piroplasms. In national literature, nucleotide sequences compatible with B. vogeli were identified in dogs of Minas Gerais, São Paulo, Goiás, Mato Grosso, Mato Grosso do Sul and Pará (Passos et al., 2005; O'Dwyer et al., 2009; Duarte et al., 2011; Spolidorio et al., 2011; Moraes et al., 2015; Sousa et al., 2017; Barbosa et al., 2020; Castro et al., 2020). Specifically in the state of Rio de Janeiro, compatible nucleotide sequence $B$. vogeli, was reported only one dog sample from the mountain region (Lemos et al., 2012). In addition to this species, in the South Brazil, only four infected dogs were detected sequences of B. gibsoni (Trapp et al., 2006).

Information about infection by these protozoa in dogs is scanty in Brazil, thus requiring more studies and reports about the use of molecular techniques in their methodology in order to distinguish piroplasms taxonomically in blood dog sample. This study therefore describes the identification of species of piroplasms contained in canine blood samples stored in the blood bank of a clinical laboratory located in the city of Niterói, RJ, Brazil, using molecular tools, and associates information about the dogs provided in the lab orders and that obtained in the complete blood counts.

\section{Material and Methods}

This study was approved by the Ethics Committee on Animal Use of Fluminense Federal University under Protocol No. 6876140318. 
Piroplasm species were analyzed by molecular tools in total 31 blood samples from positive dogs, previously checked by stained slides with the NewProv ${ }^{\otimes}$ kit, stored at $-20^{\circ} \mathrm{C}$ until DNA extraction between 2016 to 2018 in the laboratory Clinical Analyzes in Niterói, Rio de Janeiro.

DNA was extracted from the blood samples using High Pure PCR Template Preparation Kits (Roche), according to the manufacturer's instructions. At the end of the extraction, the eluted DNA was stored at $-20^{\circ} \mathrm{C}$.

The reactions were performed using a PCR master mix (Promega ${ }^{\circledR}$ ) and forward Bab143-167 (5'CCGTGCTAATTGTAGGGCTAATACA3') and reverse Bab858 - 834 (5'CCTCTGACAGTTAAATACGAATGCC3') primers designed by Soares et al. (2011) and Lemos et al. (2012), who amplified the DNA fragment that encodes the 18S rRNA of piroplasms that contain about $700 \mathrm{bp}$. The PCR products obtained in the reactions were purified using the Wizard SV Gel and PCR Clean-Up System (Promega ${ }^{\circledR}$ ), following the manufacturer's instructions. All the samples were sequenced using the same primers as those used in the PCR reactions, in a 3730xI DNA Analyzer (Applied Biosystems $\left.{ }^{\circledR}\right)$. The sequences were edited using SeqMan software and aligned to reference sequences deposited at GenBank (Figure 1). The phylogenetic tree was inferred by the neighbor-joining method, using Seaview ${ }^{\circledR}$ software, with 1,000 bootstrap replications and the Kimura 2-parameter model.

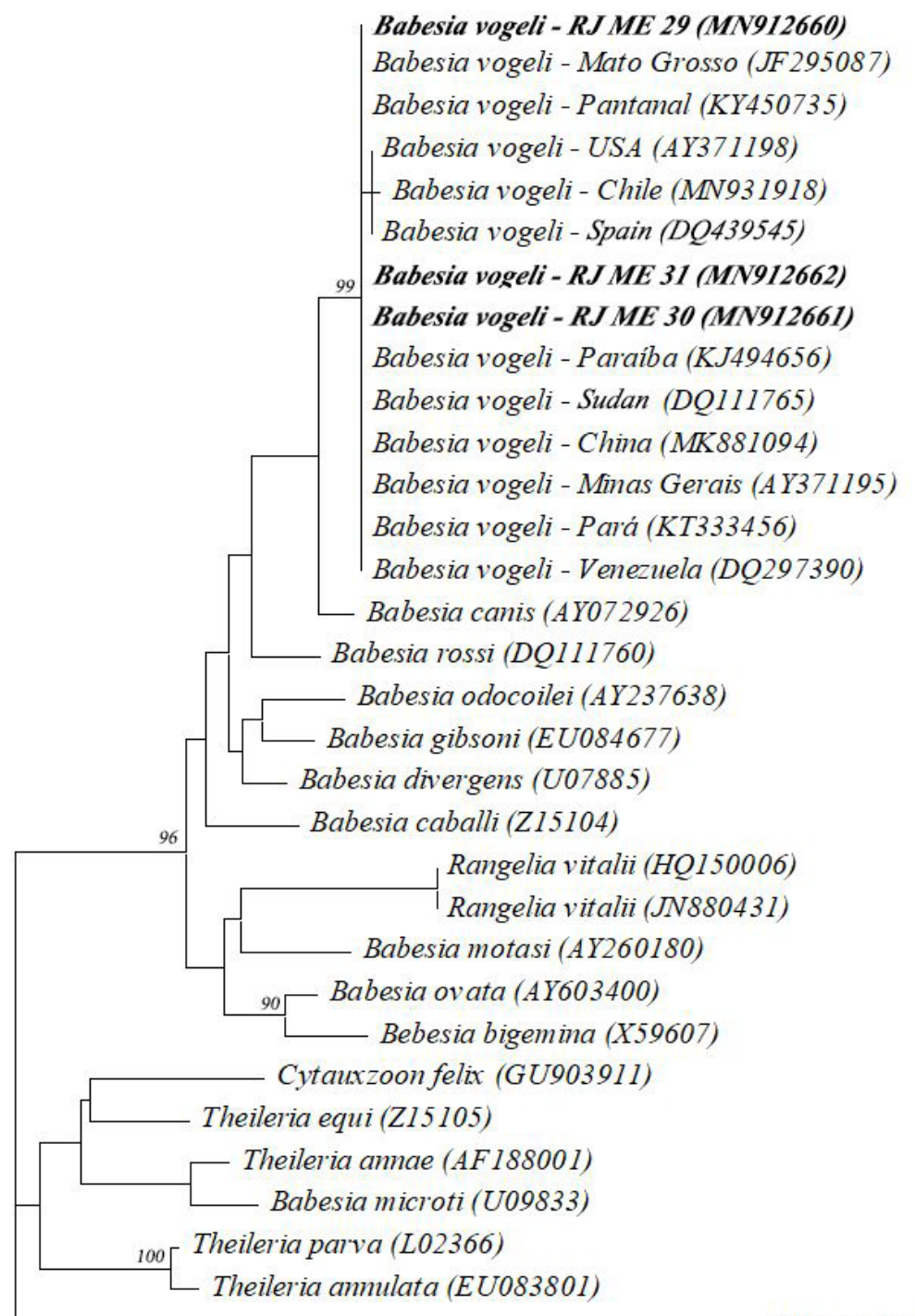

Plasmodium falciparum (M19172)

0.050

Figure 1. Phylogenetic tree generated from the DNA encoding the $18 \mathrm{~S}$ rRNA of piroplasms containing the $B$. vogeli sequence RJ ME 29 compared with other piroplasm sequences obtained from GenBank through neighbor-joining with 1000 bootstrap replications and evolutionary distance using the Kimura-2 parameter. GenBank access numbers are shown on the tree. 
In the clinical laboratory, canine blood samples in tubes containing EDTA were analyzed in a mechanical hematological system (Icounter 3D ${ }^{\circledR}$ ), which provided information on hematocrit, leukocyte count and platelet count. The reference values were those recommended by Rizzi et al. (2010) (Table 1).

Table 1. Reference hematological values for adult dogs and puppies.

\begin{tabular}{ccc}
\hline Reference hematological & References values \\
\cline { 2 - 3 } & Adult dogs & Puppies \\
\hline Hematocrit $(\%)$ & $37-55$ & $26-36$ \\
Leukomtery $\left(\mathrm{mm}^{3}\right)$ & $6000-17000$ & $6000-15000$ \\
Platelet count $\left(\mathrm{mm}^{3}\right)$ & $200.000-500.000$ & $200.000-500.000$ \\
\hline
\end{tabular}

Information such as location of the veterinary clinics that treated the dogs, and the animals' sex, breed and age, was retrieved from the lab exam orders the clinical laboratory received from those clinics. All the results of the molecular analyses were associated with the hematologic and general information about the dogs recovered de exam requests through a descriptive analysis (by means of a percentage).

\section{Results}

Among the 31 samples analyzed by PCR and sequencing, 24 (77.4\%) were positive and show adequate nucleotide sequences for interpretation with identity varying from $95.23 \%$ to $100 \%$ when compared to sequences of Babesia vogeli stored in GenBank from canine blood samples from China (MK881094), 95.5\%-99.8\% from Sudan (DQ111765), 94.7-99.7\% from Spain (DQ439545), 95-99.8\% from United States (AY371198), 96.2\%-100\% from Chile (MN931918), 95.2\%-100\% from Venezuela (DQ297390) and 93\%-100\% from Minas Gerais - Brazil (AY371195.1), 96.1\%-100\% from Mato Grosso - Brazil (JF295087), 95.2\%-100\% from Mato Grosso do Sul - Brazil (KY450735), 95.2\%-100\% from Pará - Brazil (KT333456) and 95.6-100\% from Paraíba - Brazil (KJ494656).

In general, fragments ranging from 214 to 670 bp were interpreted based on the sequences generated with Bab primers. The sequences in this study named $B$. vogeli RJ - ME (metropolitan region of Rio de Janeiro) were deposited at GenBank under access number MN912639 - MN912662. The phylogenetic analysis indicated that the sequences were grouped in the $B$. vogeli cluster, together with reference sequences presenting a $99 \%$ width bootstrap.

Most of the blood samples positive with B. vogeli were from male dogs (62.5\%) of known breeds (54.2\%) that were treated at veterinary clinics in São Gonçalo (58.3\%), and had anemia (62.5\%) and thrombocytopenia (95.8\%) and a normal white blood cell count (62.5\%) (Table 2). Among dogs with defined breeds that were infected with B. vogeli, included one American Pit Bull, one Beagle, one Boxer, one French Bulldog, three Poodle, two Yorkshire Terriers, two Shih Tzu, one Labrador and one Pinscher.

Table 2. Samples from dogs testing positive for piroplasms and Babesia vogeli in the molecular analysis, stored at the clinical laboratory in Niterói, RJ between January 2016 and April 2018, distributed among different variables.

\begin{tabular}{|c|c|c|c|c|c|}
\hline \multicolumn{2}{|c|}{ Information } & \multicolumn{2}{|c|}{$\begin{array}{l}\text { Piroplasmids detected by microscopic } \\
\text { techniques }\end{array}$} & \multicolumn{2}{|c|}{$\begin{array}{l}\text { Babesia vogeli detected by molecula } \\
\text { techniques }\end{array}$} \\
\hline & & $\mathbf{n}$ & $\%$ & $\mathbf{n}$ & $\%$ \\
\hline \multirow[t]{2}{*}{ Gender } & Male & 19 & 61.3 & 15 & 62.5 \\
\hline & Female & 12 & 38.7 & 9 & 37.5 \\
\hline \multirow[t]{3}{*}{ Age } & $\leq 1$ year old & 11 & 35.5 & 8 & 33.3 \\
\hline & $>1$ year old & 11 & 35.5 & 9 & 37.5 \\
\hline & Indeterminate & 9 & 29 & 7 & 29.2 \\
\hline
\end{tabular}

n: number. 
Table 1. Continued...

\begin{tabular}{|c|c|c|c|c|c|}
\hline \multicolumn{2}{|c|}{ Information } & \multicolumn{2}{|c|}{$\begin{array}{l}\text { Piroplasmids detected by microscopic } \\
\text { techniques }\end{array}$} & \multicolumn{2}{|c|}{$\begin{array}{c}\text { Babesia vogeli detected by molecular } \\
\text { techniques }\end{array}$} \\
\hline & & $\mathbf{n}$ & $\%$ & $\mathbf{n}$ & $\%$ \\
\hline \multirow[t]{3}{*}{ Breed } & Definite breed & 16 & 51.6 & 13 & 54.2 \\
\hline & Undefinite breed & 13 & 41.9 & 10 & 41.7 \\
\hline & Indeterminate & 2 & 6.5 & 1 & 4.2 \\
\hline \multirow[t]{4}{*}{ City } & São Gonçalo & 18 & 58 & 14 & 58.3 \\
\hline & Niterói & 8 & 25.8 & 6 & 25 \\
\hline & Itaboraí & 1 & 3.2 & 1 & 4.2 \\
\hline & Maricá & 4 & 12.9 & 3 & 12.5 \\
\hline \multirow[t]{2}{*}{ Anemia } & Yes & 22 & 71 & 15 & 62.5 \\
\hline & No & 9 & 29 & 9 & 37.5 \\
\hline \multirow[t]{2}{*}{ Platelets } & Low & 30 & 96.8 & 23 & 95.8 \\
\hline & Normal & 1 & 3.2 & 1 & 4.2 \\
\hline \multirow[t]{4}{*}{ Leucocytes } & Low & 11 & 35.5 & 9 & 37.5 \\
\hline & Normal & 18 & 58 & 15 & 62.5 \\
\hline & High & 2 & 6.5 & 0 & 0 \\
\hline & & 31 & & 24 & \\
\hline
\end{tabular}

n: number.

\section{Discussion}

All the sequences analyzed in this study were consistent with Babesia vogeli. In general, this has been the most frequently detected species in dogs in Brazil (Passos et al., 2005; Duarte et al., 2011; O'Dwyer et al., 2009; Spolidorio et al., 2011; Lemos et al., 2012, Moraes et al., 2015, Sousa et al., 2017; Barbosa et al. 2020, Castro et al., 2020) and also others countries as China, Sudan, Spain, Venezuela, Chile, and USA (Li et al., 2020; Oyamada et al., 2005; Criado-Fornelio et al., 2007; Di Cataldo et al., 2020; Rey-Valeiron et al., 2007; Passos et al., 2005).

Although this species is the one most widely reported in Brazil, other piroplasms have been identified infecting domestic dogs in this country, which are more pathogenically aggressive, such as Babesia gibsoni in the south (Trapp et al., 2006) and Rangelia vitalii in different states in the south and southeast regions of Brazil (Soares et al., 2011; Silva et al., 2019), including cities in the mountain region of the state of Rio de Janeiro (Lemos et al., 2017). Other species and even other genera that are not expected to infect domestic dogs have also been detected through molecular techniques. A new species of large, unnamed, Babesia was described infecting dogs in North Carolina, USA (Birkenheuer et al., 2004). In addition to other small piroplasms, including B. conradae (Kjemtrup et al., 2006), T. annulata (Criado et al., 2006) and T. equi (Criado-Fornelio et al., 2003) have also been detected in domestic dogs. These piroplasm species can only be accurately diagnosed by means of molecular methods, since these protozoa are morphologically similar. Hence, these infective agents should be constantly monitored in the blood banks of clinical laboratories using molecular methods to increase epidemiological information about piroplasms. Furthermore, clinical analysts should consider the inclusion of molecular analysis in the routine diagnosis of canine piroplasmosis, since a more accurate identification of the infecting agent could help veterinarians target treatments specifically, given that the sensitivity of these agents to drugs may differ, as pointed out by other authors (Loretti \& Barros, 2004; Bilic et al., 2018).

In this study, canine blood samples testing positive for piroplasms, which were stored between 2016 to 2018 in freezers at a clinical laboratory in Niterói, RJ, Brazil, were analized to a molecular biology in order to identify the species of piroplasmids. However, using the Bab primer, not all the samples showed amplicons in electrophoresis of sufficient intensity to be considered positive and not all showed nucleotide fragments suitable for interpretation. 
Despite the high sensitivity of PCR and numerous attempts to perform it with Bab primer, species could not be identified in all the samples positive for piroplasms on microscope slides. This may have been due to nucleotide degradation, which made it difficult to anneal the primer and that may have occurred due to technical problems, including low quality of the biological samples, since they were kept in a freezer for a long time.

Duarte et al. (2011), in Goiás, found a similar situation in 35 blood samples from dogs positive for piroplasms on microscope slides. In their study, only 29 samples presented amplicons, 17 of which showed nucleotide sequences of sufficiently high quality for interpretation using Bab 7 and Bab 9 primers. It also uses pairs of Bab primers (143-167/694-667) Spolidorio et al. (2011) analyzing eight infected dogs in Cuiabá - Mato Grosso, positive in thin slides stained for piroplasms, identified nucleotide sequences applied by $B$. vogeli only in six animals. Differently, Moraes et al. (2015) when analyzing 27 amplified DNA products from Babesia sp. of dogs from Belém - Pará, were able to identify all sequences amplified with $B$. vogeli. The authors reported that the easy interpretation of the nucleotide sequences was only possible, due to the cloning of the amplicon, previously performed sequencing. However, the reagents for cloning are expensive and are not used in most laboratories for clinical analysis and research.

Despite the widespread use of $18 \mathrm{~S}$ rRNA in the research of piroplasmids, this discrepancy between molecular data and parasite morphology may be due to the complexity of $18 \mathrm{~S}$ secondary structure that could lead to inconsistencies in gene alignment (Morrison \& Ellis, 1997). This fact may have impaired the identification of piroplasms in all samples analyzed. In this way, other genes, such as cytochrome $b$ and the heat-shock proteins encoding genes, have already been identified as promising targets in the research of piroplasms and can be used in association with $18 \mathrm{~S}$ (Sousa et al., 2017).

The descriptive analysis of the samples indicated that most of them came from male dogs of definite breeds. However, information about the dogs' ages revealed that the blood samples came from approximately the same number of adults and puppies. A similar report involving male dogs of known breeds was reported in Campinas, SP and Recife, PE (Benigno et al., 2011; Silva et al., 2016). In Pernambuco, the most frequently infected breeds were Pinscher and Pit Bull, but the samples of this study did not show a more frequent pattern of breeds, in other words, dogs of a variety of breeds were infected. The greatest susceptibility to infection by Babesia sp. mainly in definite breed and male dogs have already been pointed out by some authors (Imre et al., 2013; Solano-Gallego et al., 2016). However, there is no consensus in the literature with respect to these demographic variables, since piroplasms have also been frequently reported in groups of mixed breed dogs, adults and females (Trapp et al., 2006; Guimarães et al., 2009; Araujo et al., 2015). It should be noted that the sample size of this report was small, which underscores the need for more cross-sectional studies with larger numbers of samples in order to ascertain the significance of these variables based on statistical analysis.

Most of the canine blood samples examined in this study came from veterinary clinics located in São Gonçalo, in the state of Rio de Janeiro. It cannot be categorically stated that the dogs from which these blood samples came lived in São Gonçalo, but it should be noted that this city in the state of Rio de Janeiro has a very large population second only to that of the city of Rio de Janeiro. Although the size of the canine population is not known, the number of pets has been increasing along with the human population in the state of Rio de Janeiro, thus favoring the increase in the population of ticks, and of infectious agents transmitted by these vectors, such as piroplasms. It is important to note that Rhipicephalus sanguineus is the vector tick responsible for the transmission of $B$. vogeli in South America, especially in Brazil (Maggi \& Krämer, 2019) This fact also ends up favoring the endemicity of babesiosis, as $R$. sanguineus is a tick of three hosts and well adapted to the urban environment (Passos et al., 2005).

In this study, the molecular diagnosis allied to the complete blood count revealed that most of the dogs infected with piroplasms suffered from anemia and thrombocytopenia. Anemia is known to be one of the most common hematological changes in piroplasm infections, including babesiosis. However, this hematological change is not always evident when infections are caused by Babesia species with mild to moderate pathogenicity, such as Babesia vogeli (Duarte et al., 2008).

The complete blood count also showed platelet deficiency in blood samples from dogs infected with the parasite. Thrombocytopenia is almost always present in infections by piroplasms, including the genus Babesia, and is therefore considered the most important hematological alteration in canine piroplasmosis. In babesiosis, thrombocytopenia is caused by the destruction of platelets, spleen platelet sequestration, increased body temperature, and disseminated intravascular coagulation (Barić Rafaj et al., 2013). Thus, thrombocytopenia was already an expected hematological change in the blood samples from infected dogs. 
This study describes the findings of a study in which sequences of high identity with $B$. vogeli were identified in blood samples from dogs in various cities in the metropolitan region of Rio de Janeiro. The most significant hematological alteration in these blood samples was thrombocytopenia. This is the first study involving the molecular characterization of piroplasms in the metropolitan region of Rio de Janeiro, based on PCR followed by sequencing.

\section{Acknowledgements}

We would like to thank the Platform DNA Sequencing (Oswaldo Cruz Foundation, Rio de Janeiro, Brazil) for sequencing support.

\section{References}

Araujo AC, Silveira JAG, Azevedo SS, Nieri-Bastos FA, Ribeiro MFB, Labruna MB, et al. Babesia canis vogeli infection in dogs and ticks in the semiarid region of Pernambuco, Brazil. Pesq Vet Bras 2015; 35(5): 456-461. http://dx.doi.org/10.1590/S0100736X2015000500012.

Barbosa COS, Garcia JR, Fava NMN, Pereira DA, Cunha MJR, Nachum-Biala Y, et al. Babesiosis caused by Babesia vogeli in dogs from Uberlândia State of Minas Gerais, Brazil. Parasitol Res 2020; 119(3): 1173-1176. http://dx.doi.org/10.1007/s00436-01906515-3. PMid:32140779.

Barić Rafaj R, Kuleš J, Selanec J, Vrkić N, Zovko V, Zupančič M, et al. Markers of coagulation activation, endothelial stimulation, and inflammation in dogs with babesiosis. J Vet Intern Med 2013; 27(5): 1172-1178. http://dx.doi.org/10.1111/jvim.12146. PMid:23875771.

Benigno RNM, Rodrigues BRS, Serra-Freire NM. Avaliação das infecções por Babesia e Ehrlichia em cães e das infecções humanas por carrapatos oriundos desses cães no município de Campinas, Estado de São Paulo. Rev Bras Med Vet 2011; 33(4): $238-245$.

Bilić P, Kuleš J, Rafaj BR, Mrljak V. Canine babesiosis: where do we stand? Acta Vet (Beogr) 2018; 68(2): 127-160. http://dx.doi. org/10.2478/acve-2018-0011.

Birkenheuer AJ, Neel J, Ruslander D, Levy MG, Breitschwerdt EB. Detection and molecular characterization of a novel large Babesia species in a dog. Vet Parasito/ 2004; 124(3-4): 151-160. http://dx.doi.org/10.1016/j.vetpar.2004.07.008. PMid:15381295.

Castro VV, Ayres ECBS, Canei DH, Pereira ME, Sousa VRF, Chitarra CS, et al. Molecular prevalence and factors associated with Babesia vogeli infection in dogs in the Cerrado Mato-Grossense region of Brazil. Cienc Rural 2020; 50(2): e20190389. http://dx.doi. org/10.1590/0103-8478cr20190389.

Criado A, Martinez J, Buling A, Barba JC, Merino S, Jefferies R, et al. New data on epizootiology and genetics of piroplasms based on sequences of small ribosomal subunit and cytochrome $b$ genes. Vet Parasito/ 2006; 142(3-4): 238-247. http://dx.doi.org/10.1016/j. vetpar.2006.07.004. PMid:16919391.

Criado-Fornelio A, Martinez-Marcos A, Buling-Saraña A, Barba-Carretero JC. Molecular studies on Babesia, Theileria and Hepatozoon in Southern Europe: Part I. Epizootiological aspects. Vet Parasitol 2003; 113(3-4): 189-201. http://dx.doi.org/10.1016/S03044017(03)00078-5. PMid:12719133.

Criado-Fornelio A, Rey-Valeiron C, Buling A, Barba-Carretero JC, Jefferies R, Irwin P. New advances in molecular epizootiology of canine hematic protozoa from Venezuela, Thailand and Spain. Vet Parasito/ 2007; 144(3-4): 261-269. http://dx.doi.org/10.1016/j. vetpar.2006.09.042. PMid:17088022.

Dantas-Torres F, Figueiredo LA. Canine babesiosis: a Brazilian perspective. Vet Parasitol 2006; 141(3-4): 197-203. http://dx.doi. org/10.1016/j.vetpar.2006.07.030. PMid:16962707.

Di Cataldo S, Ulloa-Contreras C, Cevidanes A, Hernández C, Millán J. Babesia vogeli in dogs in Chile. Transbound Emerg Dis 2020 May 4. [Epub ahead of print]. http://dx.doi.org/10.1111/tbed.13609.

Duarte SC, Louly CCB, Silveira OJ No, Romanowski TNA, Lino RS Jr, Linhares GFC. Diagnóstico parasitológico e molecular da babesiose canina na cidade de Goiânia-GO. Rev Patol Trop 2008; 37(3): 229-236. http://dx.doi.org/10.5216/rpt.v37i3.5064.

Duarte SC, Parente JP, Pereira M, Soares CM, Linhares GFC. Phylogenetic characterization of Babesia canis vogeli in dogs in the state of Goiás, Brazil. Rev Bras Parasito/ Vet 2011; 20(4): 274-280. http://dx.doi.org/10.1590/S1984-29612011000400004. PMid:22166380.

Guimarães AM, Rocha CMBM, Oliveira TMFS, Rosado IR, Morais LG, Santos RRD. Fatores associados à soropositividade para Babesia, Toxoplasma, Neospora e Leishmania em cães atendidos em nove clínicas veterinárias do município de Lavras, MG. Rev Bras Parasitol Vet 2009;18(1 Suppl 1): 49-53. http://dx.doi.org/10.4322/rbpv.018e1009. PMid:20040191.

Imre M, Farkas R, Ilie MS, Imre K, Dărăbuş G. Survey of babesiosis in symptomatic dogs from Romania: occurrence of Babesia gibsoni associated with breed. Ticks Tick Borne Dis 2013; 4(6): 500-502. http://dx.doi.org/10.1016/j.ttbdis.2013.06.006. PMid:23994336.

Irwin PJ. Canine babesiosis: from molecular taxonomy to control. Parasit Vectors 2009; 2(Suppl 1): S4. http://dx.doi.org/10.1186/17563305-2-S1-S4. PMid:19426443. 
Kjemtrup AM, Wainwright K, Miller M, Penzhorn BL, Carreno RA. Babesia conradae, sp. Nov., a small canine Babesia identified in California. Vet Parasitol 2006; 138(1-2): 103-111. http://dx.doi.org/10.1016/j.vetpar.2006.01.044. PMid:16524663.

Köster LS, Lobetti RG, Kelly P. Canine babesiosis: A perspective on clinical complications, biomarkers and treatment. Vet Med (Auckl) 2015; 6: 119-128. PMid:30155438.

Laha R, Das M, Sen A. Morphology, epidemiology, and phylogeny of Babesia: an overview. Trop Parasitol 2015; 5(2): 94-100. http:// dx.doi.org/10.4103/2229-5070.162490. PMid:26629451.

Lemos TD, Cerqueira AMF, Toma HK, Silva AV, Corrêa RGB, Paludo GR, et al. Detection and molecular characterization of piroplasms species from naturally infected dogs in southeast Brazil. Rev Bras Parasitol Vet 2012; 21(2): 137-142. http://dx.doi.org/10.1590/ S1984-29612012000200012. PMid:22832754.

Lemos TD, Toma HK, Assad RQ, Silva AV, Corrêa RGB, Almosny NRP. Clinical and hematological evaluation of Rangelia vitaliinaturally infected dogs in southeastern Brazil. Rev Bras Parasitol Vet 2017; 26(3): 307-313. http://dx.doi.org/10.1590/s198429612017040 . PMid:28902259.

Li X-W, Zhang X-L, Huang H-L, Li W-J, Wang S-J, Huang S-J, et al. Prevalence and molecular characterization of Babesia in pet dogs in Shenzhen, China. Comp Immunol Microbiol Infect Dis 2020; 70: 101452. http://dx.doi.org/10.1016/j.cimid.2020.101452. PMid:32120143.

Loretti AP, Barros SS. Infecção por Rangelia vitalli ("Nambiuvú", “Peste de Sangue”) em caninos: revisão. Med Vet 2004; 2(6): 128-144.

Maggi RG, Krämer F. A review on the occurrence of companion vector-borne diseases in pet animals in Latin America. Parasit Vectors 2019; 12(1): 145. http://dx.doi.org/10.1186/s13071-019-3407-x. PMid:30917860.

Moraes PHG, Rufino CP, Baraúna ARF, Reis T, Agnol LTD, Meneses AMC, et al. Molecular characterization of Babesia vogeli in dogs from Belém, northern Brazil. Genet Mol Res 2015; 14(4): 16364-16371. http://dx.doi.org/10.4238/2015.December.9.4. PMid:26662431.

Morrison DA, Ellis JT. Effects of nucleotide sequence alignment on phylogeny estimation: a case study of 18S rDNAs of apicomplexa. Mol Biol Evol 1997; 14(4): 428-441. http://dx.doi.org/10.1093/oxfordjournals.molbev.a025779. PMid:9100373.

O’Dwyer LH, Lopes VVA, Rubini AS, Paduan KS, Ribolla PEM. Babesia spp. infection in dogs from rural areas of São Paulo State, Brazil. Rev Bras Parasito/ Vet 2009; 18(2): 23-26. http://dx.doi.org/10.4322/rbpv.01802005. PMid:19602312.

Oyamada M, Davoust B, Boni M, Dereure J, Bucheton B, Hammad A, et al. Detection of Babesia canis rossi, B. canis vogeli, and Hepatozoon canis in dogs in a Village of eastern Sudan by using a screening PCR and sequencing methodologies. Clin Diagn Lab Immunol 2005; 12(11): 1343-1346. http://dx.doi.org/10.1128/CDLI.12.11.1343-1346.2005. PMid:16275954.

Passos LMF, Geiger SM, Ribeiro MFB, Pfister K, Zahler-Rinder M. First molecular detection of Babesia vogeli in dogs from Brazil. Vet Parasitol 2005; 127(1): 81-85. http://dx.doi.org/10.1016/j.vetpar.2004.07.028. PMid:15619377.

Rey-Valeiron C, Criado-Fornelio A, Zavala E, Granados R. Parasitological and molecular characterization of a venezuelan isolate of Babesia canis. Rev Cient (Maracaibo) 2007; 17(1): 21-27.

Rizzi TE, Meinkoth JH, Clinkenbeard KD. Normal hematology of the dog. In: Weiss DJ, Wardrop KJ. Schalm's veterinary hematology. 6th ed. Ames: Wileyblackwell; 2010. p. 799-810.

Schoeman JP. Canine babesiosis. OnderstepoortJ Vet Res 2009; 76(1): 59-66. http://dx.doi.org/10.4102/ojvr.v76i1.66. PMid:19967929.

Silva BRF, Labruna MB, Marcili A, Santos CR, Bastos BBB, Bordin JT, et al. Rangelia vitalii infection in a dog from São Paulo city, Brazil: case report. Braz J Vet Res Anim Sci 2019; 56(3): E150791. http://dx.doi.org/10.11606/issn.1678-4456.bjvras.2019.150791.

Silva VC, Lima ER, Dias MBMC, Fukahori FLP, Rêgo MSA, Júnior JWP, et al. Parasitological and molecular detection of Babesia canis vogeli in dogs of Recife, Pernambuco and evaluation of risk factors associated. Semina: Ciênc Agrár 2016; 37(1): 163-172. http:// dx.doi.org/10.5433/1679-0359.2016v37n1p163.

Soares JF, Girotto A, Brandão PE, Silva AS, França RT, Lopes STA, et al. Detection and molecular characterization of a canine piroplasm from Brazil. Vet Parasitol 2011; 180(3-4): 203-208. http://dx.doi.org/10.1016/j.vetpar.2011.03.024. PMid:21489694.

Solano-Gallego L, Sainz Á, Roura X, Estrada-Peña A, Miró G. A review of canine babesiosis: the European perspective. Parasit Vectors 2016; 9(1): 336. http://dx.doi.org/10.1186/s13071-016-1596-0. PMid:27289223.

Sousa KCM, Fernandes MP, Herrera HM, Freschi CR, Machado RZ, André MR. Diversity of piroplasmids among wild and domestic mammals and ectoparasites in Pantanal wetland, Brazil. Ticks Tick Borne Dis 2017; 9(2): 245-253. http://dx.doi.org/10.1016/j. ttbdis.2017.09.010. PMid:28941935.

Spolidorio MG, Torres MM, Campos WNS, Melo ALT, Igarashi M, Amude AM, et al. Molecular detection of Hepatozoon canis and Babesia canis vogeli in domestic dogs from Cuiabá, Brazil. Rev Bras Parasitol Vet 2011; 20(3): 253-255. http://dx.doi.org/10.1590/ S1984-29612011000300015. PMid:21961759.

Taboada J, Merchant SR. Babesiosis of companion animals and man. Vet Clin North Am Small Anim Pract 1991; 21(1): 103-123. http://dx.doi.org/10.1016/S0195-5616(91)50011-5. PMid:2014615.

Trapp SM, Dagnone AS, Vidotto O, Freire RL, Amude AM, Morais HSA. Seroepidemiology of canine babesiosis and ehrlichiosis in a hospital population. Vet Parasito/ 2006; 140(3-4): 223-230. http://dx.doi.org/10.1016/j.vetpar.2006.03.030. PMid:16647817. 